\title{
The Corona Virus Can Infect Banks Too
}

\section{The Applicability of the EU Banking and State Aid Regimes}

\author{
Phedon Nicolaides*
}

This paper examines possible options for Member States to redress the impact of the corona virus (SARS-CoV2) on financial institutions in the context of the directive on bank recovery and resolution, the regulation on the Single Resolution Mechanism and the State aid rules on banks. The EU banking regime requires, in principle, that the granting of State aid to a bank should lead to its resolution or liquidation. The paper considers how Member States may support banks outside the scope of Article 107(1) TFEU and how State aid may be granted without triggering resolution or liquidation. The current measures which are rolled out by European governments to support the real economy will indirectly benefit banks too. The paper reviews the recently announced 'Temporary Framework' according to which any 'indirect aid' to banks will not infringe the provisions of the directive or regulation. The paper identifies gaps in the current rules concerning solvent, but not systemic banks, ambiguities in the interpretation of the concept of 'serious disturbance' and unclear guidance as to how indirect aid may be minimised.

Keywords: Bank resolution; Liquidation; Temporary Framework; COVID-19.

\section{Introduction}

The disruption to economic life caused by the corona virus [SARS-CoV2, which causes the disease known as COVID-19] pandemic will have an unavoidable negative impact on European banks. Not only are their investments unlikely to generate the returns that were expected only a couple of months ago, but, more seriously for them, there is high probability that the quality of their assets will deteriorate. This is because the assets of banks are mostly the loans they grant to companies and households. As the number of companies declaring bankruptcy rises, the share of non-performing loans in the portfolios of banks will also increase. In the end, banks may have no other option but to turn to governments for liquidity support, if not outright bail-outs.

The problem for European banks is that Directive $2014 / 59$ on the recovery and resolution of financial

DOI: $10.21552 /$ estal/2020/1/7

* Phedon Nicolaides is Professor, University of Maastricht; Visiting Professor, College of Europe, Bruges, and Luiss University, Rome. institutions [BRRD] and Regulation 806/2014 establishing the Single Resolution Mechanism [SRMR] allow bail-outs under very strict conditions. In fact, Article 32 of the BRRD and Article 18 of the SRMR stipulate that if a bank requests 'extraordinary public financial support' [EPFS] then it is considered to be 'failing or likely to fail' [FoLF]. EPFS is any public funding at EU or Member State level intended to provide capital or liquidity that would satisfy the criteria of Article 107(1) TFEU and, consequently, would be classified as State aid.

In principle, if a bank is deemed to be FoLF, it must be resolved according to EU rules or placed in liquidation according to the respective national rules. A bank is resolved when resolution is in the 'public interest' in order to protect or preserve financial stability. Resolution is in the public interest when the bank is large or 'systemically significant'. If a bank is small or 'systemically insignificant', then it is liquidated. But the situation is a bit more complex, as will be explained later one.

There is also an exception to the requirement for resolution or liquidation. EPFS may be granted for 'precautionary recapitalisation' or to improve the liq- 
uidity of solvent banks in order to remedy a serious disturbance in the economy of a Member State and to preserve financial stability.

The sequence of the application of the rules in the current legal framework can be described in concise terms as follows:

1. Is public support State aid?

Yes: [ie it is EPFS] Go to 2.

No: The BRRD, SRMR and State aid rules do not apply.

2. Is the bank solvent?

Yes: Go to 3 .

No: Go to 4 .

3. Is the aid necessary to protect financial stability?

Yes: [ie the bank is systemically significant] The bank may receive precautionary recapitalisation or liquidity support without resolution.

No: [ie the bank is not systemically significant]? 4. Is the aid necessary to protect financial stability?

Yes: [ie the bank is systemically significant] The bank is resolved and its critical functions are maintained.

No: [ie the bank is not systemically significant] The bank is liquidated according to national procedures.

It should be obvious from the scheme above that in the current rules there is a lacuna as to what happens to a bank that is solvent but not systemically significant. In fact, it will be shown in this paper that there are at least one more case of ambiguity in the current rules. It centres on the interpretation of 'financial stability' and 'serious disturbance' under the BRRD/SRMR and State aid rules, respectively.

The outbreak of the corona pandemic has also raised another serious question concerning the applicability of the BRRD/SRMR. As governments intervene to shore up the real economy, subsidies to the manufacturing and services sectors will inevitably leak into the banking sector. Banks will benefit from 'indirect' aid. Will that trigger resolution or liquidation? The few measures assessed so far by the European Commission containing indirect State aid for banks have been found to be compatible with the internal market without activation of the provisions of the BRRD/SRMR, even though indirect aid is still State aid. The reason is that the aid was not intended to bail-out banks. The new rules that were adopted by the Commission on 19 March 2020 for the pur- pose of coordinating State aid to combat the effects of COVID-19 also explain that indirect aid to banks falls outside the scope of the BRRD/SRMR, but, at any rate, that aid must be minimised.

The financial crisis of 2008 started in the banking sector, then became a sovereign debt crisis and then impacted the real economy as a result of the austerity measures that were taken to reduce public debt. Now, the health crisis has hit first the real economy and has already weakened the balance sheets of financial institutions. Hence the question arises for the second time in a dozen years how Member States can support banks without causing their resolution or liquidation. The main purpose of this short paper is to provide an answer to that question. In addition, it identifies gaps and ambiguities in the current EU banking regime and its interplay with State aid rules that create uncertainty as to the compatibility of national measures with EU law.

The structure of the paper is as follows. First, it examines how Member States can support financial institutions without that support being classified as State aid. Second, it considers the exception to the resolution or liquidation in the BRRD and the SRMR and argues that its applicability raises a number of questions which so far have not been addressed in its application in practice. Third, it explains under which conditions indirect aid to banks does not trigger their resolution or liquidation.

\section{Public Support Without State Aid}

Article 107(1) TFEU is phrased as follows:

Save as otherwise provided in the Treaties, any aid granted by a Member State or through State resources in any form whatsoever which distorts or threatens to distort competition by favouring certain undertakings or the production of certain goods shall, in so far as it affects trade between Member States, be incompatible with the internal market.

It is now well established in the case law that Article 107(1) lays down four cumulative criteria for determining whether a public measure constitutes State aid:

1) state resources are transferred to an undertaking,

2) the recipient undertaking obtains an advantage in the form of reduction of its normal costs, 
3) the advantage is selectively available only to certain instead of all undertakings, and

4) the recipient undertaking operates in a sector where there is cross-border trade and the aid distorts competition by placing the recipient in a more favourable position than its competitors.

Since the outbreak of the financial crisis in 2008 , the Commission has assessed about 650 measures addressing the crisis. Most of those measures, estimated at about 550, concerned banks and other financial institutions. The latest available statistics indicate that, between 2008 and 2017, Member States granted guarantees, injected capital and provided other liquidity to banks amounting to EUR 5200 billion. A large chunk of that aid was not utilised as it was in the form of guarantees and, fortunately, the guarantees were not called.

The vast majority of the measures implemented by Member States were approved by the Commission without objections or with conditions. In about 15-20 cases, the Commission had 'serious doubts' about the compatibility of aid and had to open the formal investigation procedure. In the end only a handful of measures were prohibited by the Commission: SA.28787, guarantees to Banco Privado Portugues; SA.33927, aid to members of Belgian financial cooperatives (Arco); SA.39451, restructuring of the Italian Banca Tercas.

In a minority of cases, the Commission concluded that the public support did not constitute State aid because one or more the criteria of Article 107(1) TFEU was not satisfied. In no case did the Commission find that cross-border trade was not affected or that competition was not distorted. Therefore, no was granted when the measure in question did not involve transfer of state resources or did not confer and advantage or was not selective. In a few cases, the aid was granted to individuals, rather than undertakings, so that it did not support an economic activity. Below is a summary of the primary reasons why public support did not constitute State aid.

\section{No Transfer of State Resources}

Resources from national deposit guarantee funds or resolution funds are state resources, even if they are capitalised by contributions from banks [eg NN 61/2009, Caja Castilla-La Mancha; Commission deci- sion $2014 / 885$, recapitalisation of Greek banks by the Hellenic Financial Stability Fund].

Funding from state-owned banks can also be counted as state resource if the funding is provided at the instigation of a public authority in order to further public policy objectives rather than contribute to the profitability of the granting bank [eg T-387/11, NVZ v Commission concerning loans by the Hungarian development bank MFB to NVZ].

Therefore, no State aid is granted when the resources do not come under the control of the state or the decision in question cannot be attributed to the state such as in the following cases:

Private resources or funds from private banking associations; ie resources not controlled by the state [eg NN 36/2008, Roskilde Bank, DK].

The decision is not attributed to the state $[\mathrm{eg}$ T-98/16 Italy v Commission [Banca Tercas] concerning capital injection by the banking association FITD].

The decision is attributed to the EU [eg deposit guarantees but only for depositors not shareholders, C-76/15, Paul Vervloet].

\section{No Advantage}

No advantage is granted when the state acts in a similar manner as a private investor:

The public investment is on pari passu terms with private investment such as when, for example, all shareholders are obliged to inject fresh capital to meet capital adequacy requirements [eg NN 40/2009, recapitalisation of Hypo Steiermark, AT].

Or, the public investment conforms with the "market economy investor principle' according to which the expected return should compensate the state for the risk it assumes and should exceed or be equal to the cost of capital of a typical, well-informed investor [eg SA.47178, recapitalisation of CGD bank, PT; SA.49094, recapitalisation and restructuring of NordLB, DE].

Or, the state or a state-owned bank purchases NPLs at market rates [eg SA.38843, Hungarian Asset Management Company (MARK)].

Or, the state offers guarantees at market rates for the securitisation of NPLs in special purpose vehicles [eg Italian 'GACS' programme: SA.43390, SA.48416, SA.51026].

The same logic applies when the state divests of its shareholding in a bank. The price at which it sells 
must be equal or less than the cost of the risk it avoids [eg T-29/10, ING v Commission, confirmed in C-224/12 P, Commission v ING, NL].

When the state is acting as a private investor, it must ignore any obligations it has assumed towards the beneficiary undertaking in its capacity as a public authority [eg T-268/o8, Land Burgenland v Commission, AT; C-579/16 P, FIH v Commission, DK].

No advantage is granted when the state acts in a similar manner as a private vendor [sale of state assets]. The sale of state assets does not confer an advantage to buyer if it is open, transparent, non-discriminatory, unconditional, and the highest bidder is chosen [eg Commission decision 2015/454, resolution of three Greek cooperative banks, \& SA.43886, resolution of cooperative bank of Peloponnese where the acquirer of assets \& liabilities, Alfa Bank, paid a market price; Commission decision 2016/1208, sale of Italian Banca Tercas to Banca Bari; Commission decision 2017/1959, sale of Danish Vestjysk Bank; SA.49275, sale of Portuguese Novo Banco].

Conditions which are normal contractual terms for facilitating the completion of a sale, such as guarantees against misinformation by the seller, do not confer an advantage in the meaning of Article 107(1) TFEU [eg sale of three Italian bridge banks, SA.39543, SA.41134, SA.43547].

Nor does a competitive sale of state assets after the granting of State aid confer any advantage to the buyer as the competitive bidding takes into account the amount of the aid [eg SA.32745, sale of Austrian Kommunalkredit; SA.52288, sale of German HSH Nordbank].

\section{No Selectivity}

A measure which is general is not selective. That is, it applies to all sectors and regions of the economy and to all types of companies. For example, the assessment of tax liability according to standard accounting and tax rules is a general measure [eg assessment of deferred tax assets in the sale of three Italian bridge banks, SA.39543, SA.41134, SA.43547].

It follows that a measure that covers the whole banking sector may still be selective [eg T-711/14 Arcofin v Commission concerning guarantees for members of financial cooperatives in Belgium].

However, selectivity is determined by the area of jurisdiction of a public authority. Therefore, 'emer- gency liquidity assistance' [ELA] provided by national central banks to support the financial system is not selective because a central bank transacts only with financial institutions. In this case, however, the ELA must be offered on terms that apply equally to all banks without discrimination under the following conditions: The bank must be solvent, the liquidity is secured against collateral, a punitive rate of interest is charged, the central banks acts autonomously, and the recipient banks benefits from no state counter-guarantee [eg NN 70/2007, first support by the Bank of England to Northern Rock].

A state guarantee to cover the borrowing of the recipient bank increases state liabilities even if the objective of the guarantee is to protect the financial interests of the central bank [eg NN 61/2009, Caja Castilla-La Mancha, ES; Commission decision 2015/454 on restructuring of the Greek Alfa Bank].

\section{Beneficiaries Are Not Undertakings}

Article 107(1) TFEU, like all the EU competition rules, applies to undertakings. An undertaking is any legal or natural person which engages in an economic activity, regardless of its status, objectives and the way it is financed.

Consequently, public support of individuals or households affected by the economic crisis was found not to constitute State aid. For example,

T-711/14, Arcofin v Commission and C-76/15, Paul Vervloet concerning compensation of individual members of cooperatives in Belgium.

Commission decision 2015/454, on the resolution of three Greek cooperative banks, \& SA.43886, on the resolution of the cooperative bank of Peloponnese, which did not involve State aid to individual deposit accounts.

SA.53520, support for primary residences, EL; SA.45004, support for first residence, CY; SA.49554, Estia, CY. In these cases, aid to individuals was not State aid. However, the aid measures provided indirect aid to banks, which was assessed as compatible with the internal market on the basis of Article 107(2)(a). Any aid to SMEs conformed with the requirements of Regulation 1407/2013 on de minimis aid but indirect aid to banks was compatible with the internal market on the basis of Article 107(3)(c).

N 179/2004, state guarantees to Finnish municipalities [they were not undertakings] \& N 715/2006, state 
funding of Finnvera, FI [it was a state agency acting on behalf of the state].

It should be noted, however, that state ownership or control is irrelevant when the recipient carries out economic activities and therefore it is classified as an undertaking [eg SA.36061, British Business Bank; SA.39793, Malta Development Bank; SA.47821, InvestNL].

\section{Public Support With State Aid Without Resolution or Liquidation}

The previous section explained under which conditions public support of banks does not constitute State aid. The purpose of this section is to examine the conditions under which public support of a bank does not lead to its resolution or liquidation.

As mentioned earlier, the granting of public support that constitutes State aid or EPFS is akin to the 'kiss of death' for a bank. The BRRD and the SRMR require that the recipient bank is either resolved or liquidated. This section outlines, first, the criteria that determine resolution or liquidation and then reviews the exceptions to this rule. It concludes by identifying a number of ambiguities in the relevant legislation and policy practice.

Article 31 BRRD and Article 14 SRMR define the following as resolution objectives:

(a) to ensure the continuity of critical functions;

(b) to avoid a significant adverse effect on the financial system;

(c) to protect public funds by minimising reliance on extraordinary public financial support;

(d) to protect covered depositors;

(e) to protect client funds and client assets.

According to Article 32(1) BRRD and Article 18(1) SRMR, resolution must be taken when all of the following conditions hold:

(a) the bank is FoLF;

(b) there is no reasonable prospect for any alternative private sector measure;

(c) resolution action is necessary in the public interest.

Pursuant to Article 32(5) BRRD and Article 18(5) SRMR, a resolution action is in the public interest when:

It is necessary for the achievement of and is proportionate to one or more of the resolution objectives and winding up of the bank under normal insolven- cy proceedings would not meet those resolution objectives to the same extent.

There is a circular reasoning here. The BRRD and SRMR define resolution objectives and require that those objectives are pursued when it is in the public interest. But then they stipulate that resolution is in the public interest when it pursues any of the resolution objectives! The only break in this circular reasoning is the requirement that action must be proportionate and normal insolvency proceedings are not as effective. Well, normal insolvency proceedings are never as effective because they do not aim to preserve financial stability or minimise reliance on taxpayers' money.

Article 32(4), BRRD, and Article 18(4), SRMR, stipulate that a bank is FoLF when:

(a) the bank infringes the requirements for continuing authorisation [eg significant losses];

(b) the assets are less than its liabilities;

(c) the bank is unable to pay its debts or other liabilities;

(d) extraordinary public financial support is required.

However, point (d) contains an exception. EPFS does not lead to the conclusion that the recipient bank is FoLF when:

In order to remedy a serious disturbance in the economy of a Member State and preserve financial stability, the EPFS is granted to solvent institutions, approved under State aid rules, is precautionary and temporary and takes any of the following forms:

(i) state guarantee to back liquidity provided by central banks;

(ii) state guarantee of newly issued liabilities; or

(iii) injection of own funds or purchase of capital instruments at prices and on terms that do not confer an advantage to the bank. The injection must be necessary to address capital shortfall established by stress tests.

Point (d) contains a contradiction. If public support is classified as EPFS, necessarily it must confer an advantage under Article 107(1) TFEU, otherwise it could not be State aid. Point (d)(iii) cannot stipulate that the EPFS does not confer an advantage. It should have required instead that the EPFS does not confer an 'undue' or 'excessive' advantage.

The following conclusion may be drawn from the above presentation of the relevant rules. As indicated in the introduction, the BRRD/SRMR does not explain what happens when a solvent but not system- 
ically significant bank receives EPFS. Presumably, the closure of a non-systemic bank would not harm the financial system, so it would not be contrary to public interest to let it be liquidated.

However, in at least two cases, the Commission assessed EPFS and found it to be in conformity with Article 32(4)(d)(iii) BRRD [or Article 18(4)(d)(iii) SRMR]. In decision SA.46558 concerning the Greek Attica Bank, the Commission first noted that ' (27) the global financial crisis can create a serious disturbance in the economy of a Member State and that measures supporting banks are apt to remedy that disturbance.' Then, given that Attica Bank was found to be solvent, '46) the Commission conclude[d] that the aid measure $\mathrm{d}[\mathrm{id}]$ not violate the intrinsically linked provisions of Directive 2014/59/EU.'

The problem here is that at that time the assets of Attica Bank were about EUR 3.5 billion while the total size of the Greek banking sector was about EUR 330 billion. In other words, the market share of Attica Bank was not more than $2 \%$. It certainly was not a systemic bank.

The other case concerned the precautionary recapitalisation of the Lithuanian Central Credit Union which had about $1 \%$ market share. In decision SA.48920, the Commission, first, found that ' (26) the measure is necessary in order to avoid a serious disturbance for the Lithuanian economy and hence the measure can be assessed under Article 107(3)(b) TFEU.'

Please note the difference in the language of the Commission. From remedying a serious disturbance in the Greek case, it shifted to avoiding a serious disturbance, even though, as the Commission itself indicated in the decision, the market share of the Lithuanian Central Credit Union was just about $1 \%$.

Then the Commission examined whether the aid measure conformed with intrinsically linked provisions of the BRRD and considered that

(56) the conditions provided in Article 32(4)(d)(iii) BRRD are met. The assessment of the measure's compatibility with the internal market under Article 107(3)(b) TFEU has already shown that the measure is granted to remedy a serious disturbance in the Lithuanian economy and to preserve financial stability in the Lithuanian banking sector.

Consequently, the Commission concluded that
(64) the conditions under which the aid measure is granted is in line with the exemption provided for in Article 32(4)(d)(iii) BRRD. Therefore, the aid measure does not trigger the 'failing or likely to fail' criterion under the BRRD in relation to the LCCU group and can be implemented outside resolution.

We must conclude that, in practice, the Commission considers that precautionary recapitalisation and liquidity support of non-systemic but solvent banks also preserves financial stability.

However, it appears that the Single Resolution Board [SRB] and the Commission have made what appears to be contradictory assessments of the need for public support of banks to preserve financial stability.

It must be conceded at this point that the since the SRB is not responsible for non-systemic banks, its views may not be relevant. The SRB manages the resolution of banks supervised by the ECB. Since the ECB supervises directly large, systemic banks, the SRB is not involved in the determination of whether the failure of a non-systemic bank could impact on financial stability and, therefore, it does not assess whether such a bank should be resolved or not.

With this qualification in mind, it is instructive to consider the case of the liquidation of two Italian banks in 2017. Banca Popolare di Vicenza and Veneto Banca were deemed to be FoLF but were not resolved by the SRB because they were not systemically significant and therefore, resolution was not in the public interest. Their failure was 'not likely to result in significant adverse effects on financial stability in Italy' [see Article 4.2.2 of the SRB decision SRB/EES/2017/11 on Veneto Banca and Article 4.2.2. of the SRB decision SRB/EES/2017/12 on Banca Popolare di Vicenza].

Yet, the Commission, in decision SA.45664,

(97) ... acknowledged that Member States should encourage the exit of non-viable players, while allowing for the exit process to take place in an orderly manner so as to preserve financial stability.

(98) According to the Italian authorities it would not be possible to avoid a serious disturbance in the economy in the areas where VB and BPVI operate .... 
(99) ... Assessing the present measures under Article 107(3)(b) TFEU is therefore fully consistent with previous cases. ${ }^{1}$

The SRB saw no threat to financial stability, while the Commission considered the aid to be necessary to preserve financial stability, even though the case law on Article 107(3)(b) is clear that the serious disturbance '(106) must affect the economy of a Member State, not merely that of one of its regions or areas' [C-301/96, Germany v European Commission] and ' (167) the disturbance in question must affect the whole of the economy of the Member State concerned, and not merely that of one of its regions or parts of its territory' [T-132/96, Freistaat Sachsen v European Commission].

Although the financial crisis had hit the entire Italian economy, a possibly disorderly exit of the two banks from the market could impact only on the local economy. Perhaps what the Commission meant was that Article 107(3)(b) allows aid to remedy the effects of a serious disturbance in the whole economy, even though the benefits from the aid are experienced locally and not across the country.

At any rate, there are ambiguous aspects in the current legal framework and its application.

\section{Indirect State Aid Without Resolution or Liquidation}

In at least three aid schemes [SA.53520, support for primary residences, EL; SA.45004, support for first residence, CY; SA.49554, Estia, CY], the Commission considered that the direct beneficiaries were not undertakings, but the schemes contained indirect State aid for banks. Nonetheless, the provisions of the BRRD and SRMR were found to be inapplicable because the aid was not intended to support banks and the indirect aid could not be classified as EPFS.

Article 2(28) BRRD and Article 3(29) define EPFS as follows:

1 Other decisions of the Commission reach different conclusions. For example, Commission decision NN 25/2008 on State aid for WestLB, recitals 40-42, and decision 2009/341 on State aid for SachsenLB, recitals 93-95, make clear that the troubles of one institution and or the disturbance of one region do not fall with the scope of the concept of serious disturbance in the [entire] economy of a Member State in Article 107(3)(b).
'Extraordinary public financial support' means State aid within the meaning of Article 107(1) TFEU, or any other public financial support at supra-national level, which, if provided for at national level, would constitute State aid, that is provided in order to preserve or restore the viability, liquidity or solvency of [a financial] institution.

For example, in the most recent measure which was the Greek scheme for the support of primary residences approved in 2019, the Commission explained that

(71) The Scheme's objective is two-fold depending on whether the direct beneficiary constitutes an undertaking or not. In the first case, the aid objectively pursues the social goal of Article 107(2)(a) TFEU. In the second case, the aid objectively pursues the goal of addressing the social hardships particular to the vulnerabilities faced by small entrepreneurs under Article 107(3)(c) TFEU. Nevertheless, in both cases, the predominantly social objective indicates that the Scheme's objective is not to preserve or restore the viability, liquidity or solvency of a bank. The Financial Institutions benefit only indirectly through the aid to the two categories of Eligible Borrowers.

(72) Furthermore, it is expected that the size of the support to each Financial Institution would anyway not be sufficiently large to have a material effect on the viability, liquidity or solvency of the bank.

In the older Cypriot scheme that was approved in 2016, the Commission first explained that the EPFS

(66) definition implies that (i) that the bank is fragile or already in difficulty and (ii) that the size of the support is sufficiently large to have a material effect on the viability, liquidity or solvency of the bank.

(67) The Commission notes that the two conditions are not fulfilled based on the following grounds: (i) The Cypriot authorities committed that in case any financial institution falls into difficulties, ..., any new aid to the primary beneficiaries under the Scheme (households as well as micro-companies) will be terminated ... (ii) The 
Scheme is open to all banks whose clients will be deemed eligible for the grant (individuals or micro companies), so it is not possible to provide an ex-ante assessment of the exact aid effect on each particular bank. However, the total budget of the Scheme is so small compared to the stock of NPLs and compared to the capital of the banks active in Cyprus that it cannot result in any material effect on any of the financial institutions' viability, liquidity or solvency.

In conclusion, indirect aid to banks which is not intended to improve their solvency or liquidity and the amount of aid is small in relation to their needs would not fall within the scope of the BRRD or SRMR and, therefore, would not lead to resolution or liquidation.

\section{The Temporary Framework: Avoidance of Direct Aid and Minimisation of Indirect Aid to Banks}

DG Competition of the European Commission has issued a 'Temporary Framework' which allows Member States to grant State aid to combat the effects of COVID-19 under harmonised rules to prevent excessive cross-border distortions. ${ }^{2}$ It has already approved the first State aid measure to counteract the initial fallout from COVID-19, which was adopted by Denmark. $^{3}$

DG Competition has also set up a special website on measures for dealing with the fallout from the covid-19 pandemic: <https://ec.europa.eu/ competition/state_aid/what_is_new/covid_19.html $>$.

Since direct aid to banks leads to resolution or liquidation, unless it is precautionary, temporary and goes to solvent banks, the Temporary Framework requires Member States not to implement measures that involve direct aid to banks and to minimise any indirect aid.

COVID-19 qualifies as an exceptional occurrence for which aid may be granted on the basis of Article $107(2)(b)$ to 'make good the damage' caused by that occurrence. However, the Temporary Framework allows for State aid on the basis of Article 107(3)(b) to 'remedy a serious disturbance in the economy of a Member State'. When the Commission issued its Communication on 'Coordinated economic response to the COVID-19 Outbreak' on 13 March 2020, ${ }^{4}$ it con- sidered that only one Member State - Italy - had experienced a negative impact of significant magnitude spanning the entire economy. Yet, within a week and as the epidemic morphed into pandemic, the Commission changed its view and now acknowledges that the entire economies of Member States are affected.

The Communication of 13 March 2020 stated that

aid granted by Member States to banks under Article 107(2)(b) TFEU to compensate for direct damage suffered as a result of the COVID-19 outbreak ... does not have the objective to preserve or restore the viability, liquidity or solvency of an institution or entity. As a result, the aid would not be qualified as extraordinary public financial support. [p 6]

The Communication of 19 March 2020 on the Temporary Framework further elaborated that aid granted via banks to undertakings in the real economy in the form of loans or guarantees will not be considered to be aid for the banks themselves.

(29) While [aid on the basis of Article 107(3)(b) TFEU in the form of loans and guarantees to undertakings impacted by covid-19] is directly targeting undertakings facing a sudden liquidity shortage and not credit institutions or other financial institutions, it may also constitute an indirect advantage to the latter. Nevertheless, such indirect aid does not have the objective to preserve or restore the viability, liquidity or solvency of the credit institutions. As a result, the Commission considers that such aid should not be qualified as extraordinary public financial support according to Article 2(1) BRRD and Article 3(1) SRM-R, and should not be assessed under the State aid rules applicable to the banking sector.

2 Commission Communication, Temporary Framework for State aid measures to support the economy in the current COVID-19 outbreak, C(2020) 1863 final, 19 March 2020. It can be accessed at: <https://ec.europa.eu/competition/state_aid/what_is_new/sa _covid19_temporary-framework.pdf>.

3 Commission decision SA.56685, aid for cancellation of events due to covid-19. It can be accessed at: <https://ec.europa.eu/ competition/elojade/isef/case_details.cfm?proc_code=3_SA_56685>

4 Commission Communication, Coordinated economic response to the COVID-19 Outbreak, COM(2020) 112 final, 13 March 2020. It can be accessed at: <https://ec.europa.eu/info/files/ communication-economic-aspects-covid-19-crisis_en $>$. 
In its introduction, the Temporary Framework contains the following additional explanation:

(7) If due to the COVID-19 outbreak, banks would need direct support in the form of liquidity recapitalisation or impaired asset measure, it will have to be assessed whether the measure meets the conditions of Article 32(4)(d) (i), (ii) or (iii) of the BRRD. Where the latter conditions were to be fulfilled, the bank receiving such direct support would not be deemed to be failing-or-likely-to-fail. To the extent such measures address problems linked to the COVID-19 outbreak, they would be deemed to fall under point 45 of the 2013 Banking Communication, which sets out an exception to the requirement of burden-sharing by shareholders and subordinated creditors.

Point 45 of the Banking Communication states that

an exception to the requirements in points 43 and 44 [which lay down the burden-sharing requirement] can be made where implementing such measures would endanger financial stability or lead to disproportionate results.

So far no state intervention in favour of banks has succeeded to benefit from the exception in point 45 on the grounds that financial stability would be endangered and in only two cases the Commission has concluded that the burden-sharing would be disproportional [Commission decision 2014/885 on the restructuring of Eurobank in Greece and SA.36249 on Banco CEISS in Spain].

At any rate, the explanation in paragraph 7 of the Temporary Framework is not completely clear. It seems to be suggesting the following. If a bank is solvent, as required by Article 32(4)(d) BRRD [or 18(4)(d) SRMR], and it needs additional capital or liquidity that would be classified as State aid, shares and bonds will not be written down or converted to capital, respectively.

However, the explanation in paragraph 7 of the Temporary Framework leaves the following two questions unanswered. First, what happens when COVID-19 causes a high enough number of bankruptcies in the real economy, which in turn have a precipitous impact on the quality of the assets of a bank and, technically, it becomes insolvent. The exception in Article 32(4)(d) BRRD or 18(4)(d) SRMR cannot apply. But the problem would be caused by COVID-19. Would the exception in point 45 apply? That is, would the bank be resolved or liquidated without burden-sharing or bail-in of the shareholders and creditors? In legal hierarchy, the requirements of the BRRD/SRMR prevail over Commission guidelines.

Second, what happens when the aided bank is solvent but not systemically significant? Not only is the application of Article $32(4)(d)$ BRRD or $18(4)(d)$ SRMR uncertain for the reason explained in the previous sections, but now the application of point 45 is uncertain too because it refers to burden-sharing that 'would endanger financial stability'. Presumably, a non-significant bank could not endanger financial stability.

Therefore, the following tentative conclusions may be drawn from the above considerations. First, regardless of whether the aid is granted on the basis of Article 107(2)(b) or Article 107(3)(b), any indirect benefits for banks will not trigger bank resolution or liquidation. However, in order to remain outside the scope of the BRRD/SRMR, any indirect aid must be minimised. According to the Temporary Framework, this can be achieved by ensuring that banks

(31) to the largest extent possible, pass on the advantages of the public guarantee or subsidised interest rates on loans to the final beneficiaries. The financial intermediary shall be able to demonstrate that it operates a mechanism that ensures that the advantages are passed on to the largest extent possible to the final beneficiaries in the form of higher volumes of financing, riskier portfolios, lower collateral requirements, lower guarantee premiums or lower interest rates.

Second, the guidance in paragraph 31 of the Temporary Framework, although welcome, is not enough because at this stage no one knows the 'higher', 'riskier' or 'lower' level or rate that would ensure that any advantages are sufficiently passed on to final beneficiaries. Since COVID-19 has impacted entire economies, normal risk indicators are unlikely to be valid any more. Banks will have to recalibrate their models and will likely ask for higher collaterals or charge higher rates to reflect new uncertainties. On the one hand, incidental benefits to banks from State aid to the real economy will not automatically trigger resolution or liquidation. One the other, however, it is unknown at this stage how, in practice, banks 
can demonstrate that they pass on benefits to 'the largest extent possible'.

Third, in case banks need direct aid, the uncertainty concerning the treatment of solvent but small banks remains.

Fourth, in case the bank that needs direct aid becomes insolvent as a result of COVID-19-related bankruptcies, the value of the exception of the Temporary Framework in relation to the $\mathrm{BRRD} / \mathrm{SRMR}$ is unclear.

\section{Conclusions}

This paper has reviewed the conditions under which public support or public investment in banks constitutes State aid and the conditions under which it does not. The EU banking regime requires that the granting of State aid to a bank should lead to its resolution or liquidation. Therefore, this paper has also examined an exception to the banking rules that allows State aid without triggering the resolution or liquidation of banks.
The current measures which are rolled out by European governments to support the real economy will indirectly benefit banks too. Although, they will not trigger their resolution or liquidation, there is uncertainty as how it can be proven that indirect benefits are minimised. It is also unclear how banks will be treated if they need direct aid as a result of deterioration in the quality of their assets caused by COVID-19.

The paper has also identified a gap in the rules concerning solvent, but not systemic banks that receive precautionary recapitalisation or temporary liquidity support. In their case too, the Temporary Framework has not shed any light on how they may be treated if they need direct aid and whether their shareholders and creditors will avoid bail-in if it is not necessary to preserve financial stability.

The paper has also questioned the interpretation of 'financial stability' and its link with the rationale for aid to remedy a 'serious disturbance' in the economy of a Member State. Governments and banks will surely welcome clarification of these issues. 